\title{
Conceptual Model Construction of Accounting Practitioners' Employability in Business English Major Graduates
}

\author{
Jingchao Zhang ${ }^{1, a}$ and Shili $\mathrm{Ge}^{1,2, \mathrm{~b}^{*}}$ \\ ${ }^{1}$ School of English for International Business, Guangdong University of Foreign Studies, Guangzhou, \\ China \\ ${ }^{2}$ Guangdong Collaborative Innovation Center for Language Research \& Service, Guangdong \\ University of Foreign Studies, Guangzhou, China \\ a774588349@qq.com, bgeshili@gdufs.edu.cn \\ ${ }^{*}$ Corresponding author
}

Keywords: Business English, Employability, Accounting practitioners, Occupational ability of accounting.

\begin{abstract}
This paper first reviews the development and definition of employability and then analyzed one influential employability model, the Key to Employability Model. To investigate the employability of accounting practitioners among Business English (BE) graduates, the authors suggest to specify the professional knowledge and skills in traditional employability model as English ability plus occupational ability of accounting. The authors construct the Four-Dimension Employability Model of Accounting Practitioners among Business English Graduates based on the Key to Employability Model and the Occupational Ability of Accounting. This model divides the employability of accounting practitioners among BE graduates into English ability \& occupational ability of accounting, generic skills, emotional intelligence and career development learning.
\end{abstract}

\section{Introduction}

Since the establishment of Business English (BE) program in 2007, it has witnessed rapid development in China. The educational objective of BE program is to cultivate talents with English and business skills. Among the various business skills, accounting is one of the most popular choices for students. Accounting has long been regarded as "the language of business" and it touches upon every aspect of life. A country's economic development cannot be separated from it. Due to the importance of accounting, more and more BE students choose it as an important skill and would devote themselves to accounting industry after graduation. Under such circumstances, it is worth thinking and exploring the employment situation of accounting practitioners among BE graduates and whether they can meet the needs of enterprises. To measure their qualification, first we need an employability measurement tool with a high degree of reliability and validity for accounting practitioners among BE graduates. Current studies on employability have not covered this specific field of BE. By testing the reliability and validity many times during the process of invention and development can an effective measurement tool be designed.

\section{An Overview of Employability}

2.1 The Development of the Concept of Employability. The concept of "employability" was first put forward by Beveridge in 1905 [1]. He argued that "employability" refers to the ability of individuals to acquire and maintain a job. Although it is over 100 years since 'employability' emerged as a concept in debates surrounding unemployment and labor markets, the term has not been in the spotlight until the 1990s. During the decades afterward, the study of employability has shifted from the macro level of government policy to promote full employment in times of weak economy to the micro level of individuals' ability to acquire jobs and keep employable in the changing labor market. The United Nations (UN) has made employability one of its four priorities for national policy 
action on youth employment and 'employability' plays a crucial role in informing labor market policy in the UK, the EU and beyond [2].

2.2 Definition of Employability. Although employability became a buzzword in organisational literature, no clear consensus about its meaning and measurement can be found [3]. Employability remains a difficult concept to measure and define [4]. The issue has been largely framed by the perspectives of policy-makers and employers.

Hillage and Pollard [5] define it as the capability to move self-sufficiently within the labour market to realise potential through sustainable employment. For an individual, employability depends on the knowledge, skills and attitudes they possess, the way they use those assets and present them to employers and the context (e.g. personal circumstances and labour market environment) within which they seek work. Researchers indicate that although definitions of employability are abundant, each emphasizing a diversity of career aspects of (potential) employees, but all referring to the possibility to obtain and to keep employment as an outcome [6].

\section{Analysis of Employability Model}

Many scholars have put forward employability models, but some are too elaborate or too simple to put into practical use. The "CareerEDGE-The Key to Employability" model brought forward by Lorraine Dacre Pool and Peter Sewell in 2007 is more influential in this field [7].

The model illustrates the essential components of employability and also suggests the direction of interaction between the various elements. This model includes five main elements: Degree Subject Knowledge, Understanding and Skills, Generic Skills, Emotional Intelligence, Career Development Learning and Experience - Work and Life. Apart from this, the model also suggests that by reflecting on and evaluating the five essential elements will result in the development of the three "Ss", that is self-efficacy, self-confidence and self-esteem, and finally improve the employability of graduates. The clear definition of the essential elements of the model and their direction of interaction provides enlightenment for further development of employability evaluation tools and employability cultivation.

\section{Occupational Ability of Accounting}

4.1 Definition of Occupational Ability of Accounting. In practical work environment, ability is the refined capacity to judge, choose and practice gained from the known knowledge coupled with the accumulation of experience which would then help people gain positive praise and respect of others. From the perspective of cultivation of talents, Yang [8] thinks that ability refers to the accumulation of professional knowledge and the formation of occupational quality. In practice, we can define "occupational ability of accounting" as the ability to perform a high standard of work in an efficient and appropriate manner with the use of unique combination of accounting skills, technology and knowledge.

4.2 Components of Occupational Ability of Accounting. There are many studies about the components of occupational ability of accounting in China. Guo [9] argued that occupational ability of accounting includes three aspects: knowledge, competence and virtue. Zheng [10] suggested that occupational ability of accounting should be divided into basic accounting skills, accounting professional ability, core competence of accounting and development ability.

Although there's no unanimous result reached on the construction of occupational ability of accounting, most of them are basically the same with only some slight differences. Xie [11] conducted a survey on more than 30 medium-and-small-sized enterprises (MSE) and found out the most required occupational abilities of accounting are as follows. (1) Professional ability, which includes accounting ability, computer and financial software application ability, economic business judgment ability, financial analysis ability and tax handling ability; (2) the ability to learn and solve problems, which includes the ability to learn autonomously, the ability to process information and the ability to solve problems; (3) social adaptability, which includes good communication and 
cooperation ability as well as organization and coordination ability; (4) the ability to invest and finance; (5) Abide by the accounting professional ethics.

\section{Conceptual Model of Accounting Employability}

At present, most of the studies of employability focus on the group of all graduates. As each profession requires different abilities, it is necessary to design different employability model specifically.

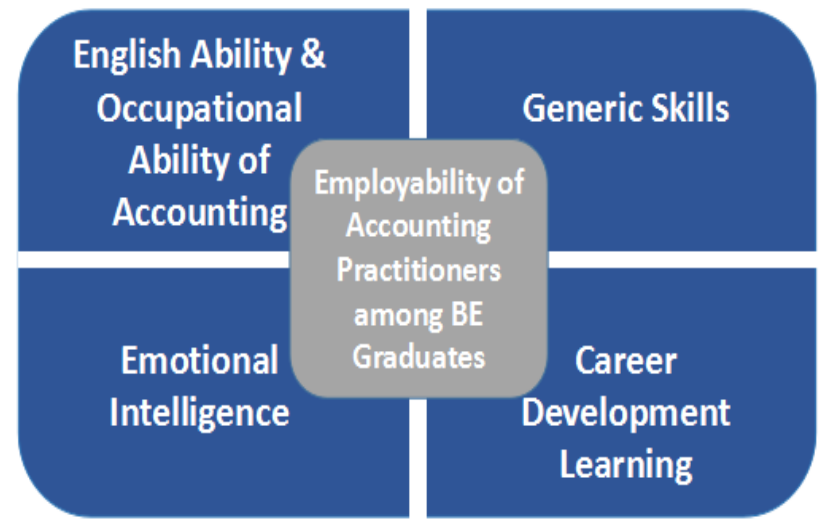

Fig. 1. Employability Model of Accounting Practitioners of Business English Graduates.

Based on the Key to Employability Model and the Occupational Ability of Accounting, we present the conceptual model of the employability of accounting practitioners among BE graduates. This framework includes four dimensions (See Fig. 1). It is important to mention that although the work and life experience may also influence the employability of graduates, it is uncontrollable and cannot be changed by education or individual efforts, thus we simplified the model of employability of accounting practitioners among BE graduates into four dimensions. In view of the current situation of our economic development and the demands of labor market, professional skill is a comparative advantage for graduates. For accounting practitioners among BE graduates, professional skills mainly refer to English ability and occupational ability of accounting. Except for professional skills, it is of vital importance for graduates to have generic skills, emotional intelligence as well as career development learning in social and interpersonal relationships.

Each dimension in this model contains different elements of employability. To clarify these elements, further research is needed.

\section{Summary}

The above model is the theoretical basis for the measurement and evaluation of the employability of accounting practitioners among BE graduates. There is still a lot to be done to transfer this conceptual model into operable survey scale. First of all, it is necessary to design a preliminary scale and test it in a certain range. Then adjust the scale and test it again. Repeat this work many times until the scale reaches a certain degree of reliability and validity. At this moment can the scale measured on a large number of samples, but still need to make appropriate adjustments.

\section{Acknowledgements}

This research was supported by the Key Research Projects of Philosophy and Social Science of Ministry of Education of China (15JZD048), Higher Education Reform Project of Guangdong Province (GDJG20141094) and Graduate Education Innovation Plan of Guangdong Province (2015JGXM-MS22). 


\section{References}

[1] R. W. McQuaid, A. Green and M. Danson, Introducing Employability, Urban Studies, vol. 42, pp. 191-195, 2005.

[2] R. W. McQuaid and C. Lindsay, The Concept of Employability, Urban Studies, vol. 42, pp. 197-219, 2005.

[3] A. Forrier and L. Sels, The concept employability: A complex mosaic. International Journal of Human Resources Development and Management, vol. 3, pp. 102-124, 2003.

[4] L. Harvey, Defining and Measuring Employability, Quality in Higher Education, vol. 7, pp. 97-109, 2001.

[5] J. Hillage and E. Pollard, Employability: developing a framework for policy analysis, Research Brief, 85, 1998.

[6] Z. Guo, and B. Heijden, Employability enhancement of business graduates in China, Education + Training, vol. 50, pp. 289 - 304, 2008.

[7] L. D. Pool and P. Sewell, The key to employability: developing a practical model of graduate employability, Education + Training, vol. 49, pp. 277-289, 2007.

[8] X. Yang, Construction of students' professional competence framework based on employment orientation, Communication of Finance and Accounting, vol. 30, pp. 98-100, 2009.

[9] J. Guo, Research on accounting education model based on accounting professional ability, Green Finance and Accounting, vol. 25, pp. 55-56, 2010.

[10]X. Zheng, Study on practical teaching reform of accounting practice teaching according to the orientation of professional ability, Higher Education Forum, vol. 27, pp. 41-43, 2011.

[11]D. Xie, Study on docking problem between accounting vocational education and employment environment, Hunan university, 2009. 